\title{
The First Look in Autism Spectrum Disorder (ASD) Geographical Distribution in National Reference Hospital, South Sumatera Region, Indonesia
}

\author{
Ziske Maritska ${ }^{1, *}$, Bintang Arroyantri Prananjaya ${ }^{2}$, Nita Parisa $^{3}$ \\ ${ }^{1}$ Department of Biology Medicine, Faculty of Medicine, Universitas Sriwijaya, Palembang, Indonesia \\ ${ }^{2}$ Department of Psychiatry, Faculty of Medicine, Universitas Sriwijaya, Palembang, Indonesia \\ ${ }^{3}$ Department of Pharmacology, Faculty of Medicine, Universitas Sriwijaya, Palembang, Indonesia \\ *Corresponding author E-mail: ziske_kamil@yahoo.com
}

Received : January $19^{\text {th }} 2020$

Accepted : March $27^{\text {th }} 2020$

\begin{abstract}
Background
ABSTRACT

Autism Spectrum Disorder (ASD) is a complex neurodevelopmental condition characterized with disorders in cognitive, behaviour, and social interaction. It is estimated to affect 1:160 children worlwide. Despite its increasing trend, the exact cause of it is yet to be known.
\end{abstract}

Methods

Medical records of the patients who are diagnosed with ASD during 2014-2018 was observed in order to identify the patients' residential area.

Results

There were 107 patients who were clinically diagnosed of having ASD during 2014-2018 in Dr Mohammad Hoesin Hospital, Palembang. Based on its residential area, ASD cases were mostly found in Palembang as the capital city of South Sumatera Province.

Conclusion

ASD is found in small and big cities across the South Sumatera province, implying its common occurrence. The varied prevalence could be signifying the role of different related risk factors identified in the area.

Keywords: Autism Spectrum Disorder, ASD, Geographical Distribution, Prevalence.

\section{Introduction}

Based on the latest Diagnostic Manual of Mental Disorders (DSM)-5 criteria, Autism Spectrum Disorder (ASD) is a neurodevelopmental disorders marked by two cardinal symptoms: impairment in social communication and social interaction, along with restricted and repetitive patterns of interests, activities, and/or behavior. ${ }^{1}$ 
ASD is long known as a multifactorial disease, with elusive causes and many related risk factors, ranging from genetic risk factors to environmental risk factors. ${ }^{2}$

WHO reported that ASD affected one in 160 children worldwide, although its prevalence varied from one country to another. ${ }^{3}$ The variation found in various countries signifying a geographical variation of ASD cases, although its causes are yet to be elucidated.

To date, there is no exact data about ASD prevalence in Indonesia, let alone in South Sumatera Region. Thus, this study wished to identify the prevalence of ASD along with its geographical distribution in South Sumatera Region based on the cases found in one of the national reference hospitals, Dr. Mohammad Hoesin Hospital.

\section{Methods}

Patients who were diagnosed with ASD during the year 2014-2018 were included in this study. All the patients had been examined thoroughly and been clinically diagnosed by competent in-charge doctor in Dr. Mohammad Hoesin Hospital. Medical records of the patients who met the criteria were then observed to identify their residential areas to map the geographical distribution of ASD patients in South Sumatera Region.

\section{Results}

As many as 107 patients who came to Dr Mohammad Hoesin Hospital during 2014-2018 and fit the inclusion criteria were deemed as participants in the study. Based on the investigation of patients' address in their medical records, ASD patients were further classified into two groups. Those who reside in South Sumatera Province, and those who reside in other provinces but still in the South Sumatera region. From the medical records, it was known that almost all ASD patients were from South Sumatera Province, with a total of 106 patients (99.1\%). Only one patient came from other province, which is Bengkulu (0.9\%). The distribution of ASD patients geographically can be seen in table 1 below. Majority of the patients in this study (86\%) were males, leaving the rest of it (14\%) were females, as it can be seen in table 2. The mean age of patients with ASD upon admission and/or the first time seeking for treatment were 47.33 months. 
ISSN 25980580

Table 1. Distribution of ASD Patients Based on Residential Area

\begin{tabular}{lll}
\hline Residential Area & n & \% \\
\hline South Sumatera Province & & \\
Palembang & 80 & 74,8 \\
Pagar Alam & 1 & 0,9 \\
Prabumulih & 2 & 1,9 \\
Lubuk Linggau & 2 & 1,9 \\
Ogan Komering Ulu & 2 & 1,9 \\
Ogan Komering Ulu Timur & 1 & 0,9 \\
Ogan Komering Ilir & 4 & 3,7 \\
Muara Enim & 2 & 1,9 \\
Lahat & 1 & 0,9 \\
Musi Banyuasin & 1 & 0,9 \\
Banyuasin & 6 & 5,6 \\
Ogan Ilir & 3 & 2,8 \\
Empat Lawang & 1 & 0,9 \\
Other Provinces & & \\
Bengkulu & 1 & 0,9 \\
\hline Total & 107 & 100 \\
\hline
\end{tabular}

Table 2. Distribution of ASD Patients Based on Sex

\begin{tabular}{lll} 
Sex & $\mathrm{n}$ & $\%$ \\
\hline Males & 92 & 86 \\
Females & 15 & 14 \\
\hline
\end{tabular}

\section{Discussion}

Males are statistically prone to suffer from ASD based on previous studies.. The finding in this study is also consistent with the existing theory, with most of the participants in the study were males (86\%). ${ }^{4}$ The sex bias in ASD prevalence towards males is thought to have few sex-differential genetic and hormonal factors although its clear mechanism is yet to be understood. ${ }^{5}$

As it is estimated, the prevalence of ASD worldwide is around one in 160 children. This figure has increased in the last twenty years in United States and also in other countries. ${ }^{6}$ This increment is likely to be caused by some factors, such as increase in knowledge and awareness of ASD among people ${ }^{7}$, changes in diagnostic criteria ${ }^{8}$, easy access and availability of 
diagnostic resources ${ }^{9}$. Despite all the possible related factors to the increment of ASD prevalence, its etiology remains unclear.

To date, there were not many studies tried to assess the geographical distribution of ASD. One study by Hoffman in $2017^{10}$ indicated that diagnostic factors are driving spatial patterns. It was found in the study that children who were born in New England had fifty percent higher chance of being diagnosed with ASD compared to other children that were born in other places in the United States. Another study conducted by the same author as well in 2012 showed that there were spatial variation of ASD in central North Carolina where the study took place ${ }^{11}$. These variations can be explained mostly by factors that affect how diagnosis were made. Combining these two factors; geographical variation and related risk factors, a predictive model of ASD trend can be constructed. The same findings were also found in this study where the prevalence of ASD varied from one city to another, ranging from one case to eighty cases in a city. Reasons behind this finding is most likely the same reason that applied in the previous two studies before.

\section{Conclusion}

As one of the national reference hospitals, Dr. Mohammad Hoesin Hospital serves as a hospital that provides health care to people in South Sumatera Region. Palembang as the capital city of South Sumatera Province is a home to majority of ASD cases found in South Sumatera Region. Nonetheless, the varied prevalence in various cities across South Sumatera Region could possibly be caused by the varying related risk factors as well. Further investigation regarding geographical distribution and its relationship with geographical distribution is needed.

\section{References}

1. Diagnostic and Statistical Manual of Mental Disorders: Diagnostic and Statistical Manual of Mental Disorders, Fifth Edition. Arlington, VA: American Psychiatric Association, 2013.

2. Griesi-Oliveira, Karina, \& Sertié, Andréa Laurato. (2017). Autism spectrum disorders: an updated guide for genetic counseling. Einstein (São Paulo), 15(2), 233-238.

3. Mayada et al. Global prevalence of autism and other pervasive developmental disorders. Autism Res. 2012 Jun; 5(3): 160-179. 
ISSN 25980580

4. Werling DM, Geschwind DH. Sex differences in autism spectrum disorders. Curr Opin Neurol. 2013;26 (2):146-153.

5. Stone JL, Merriman B, Cantor RM, et al. Evidence for sex-specific risk alleles in autism spectrum disorder. Am J Hum Genet. 2004;75 (6):1117-23.

6. Centers for Disease Control and Prevention (CDC) Prevalence of autism spectrum disorder among children aged 8 years-autism and developmental disabilities monitoring network, 11 sites, United States, 2010 MMWR Surveill Summ 2014;63(2):1-21.

7. King M, Bearman P. Diagnostic change and the increased prevalence of autism. Int $J$ Epidemiol . 2009;38(5):1224-1234.

8. Liu KY, King M, Bearman PS. Social influence and the autism epidemic. AJS. 2010; 115 (5):1387-1434.

9. Kalkbrenner AE, Daniels JL, Emch M, et al. Geographic access to health services and diagnosis with an autism spectrum disorder. Ann Epidemiol. 2011;21(4):304-310.

10. Kate Hoffman, Marc G. Weisskopf, Andrea L. Roberts, Raanan Raz, Jaime E. Hart, Kristen Lyall, Elin M. Hoffman, Francine Laden, Verónica M. Vieira, Geographic Patterns of Autism Spectrum Disorder Among Children of Participants in Nurses' Health Study II, American Journal of Epidemiology, Volume 186, Issue 7, 1 October 2017, Pages 834-842

11. Hoffman, K., Kalkbrenner, A.E., Vieira, V.M. et al. The spatial distribution of known predictors of autism spectrum disorders impacts geographic variability in prevalence in central North Carolina. Environ Health 11, 80 (2012) doi:10.1186/1476-069X-11-80. 
ISSN 25980580 